\title{
Attitude Towards Cross-Culture Exchange in the 1685 French Embassy to the Kingdom of Siam
}

\author{
Benjamin Beese \\ Middlebury College
}

On 3 March 1685, six Jesuit priests launched from Brest, France aboard the sailing ship Oiseau with the goal of landing in the Kingdom of Siam seven months later. ${ }^{1}$ The Oiseau was loaded with astronomical charts, telescopes, books on natural history, quadrants, pendulums, other scientific instruments, and instructions from the Academy Royal for observations to make while abroad. ${ }^{2}$ The frigate Maligne accompanied the Oiseau, carrying an ambassador, the Chevalier de Chaumont; presents from King Louis XIV of France, and "the great many Bales of all sorts of Curiosities which the King of Siam had sent for, both from France and England."3 This expedition was inspired by a Siamese embassy received by Louis XIV in $1684 .{ }^{4}$ Louis XIV hoped that King Narai of Siam (r. 1656-1688) "might turn Christian, if there were an Ambassador sent to him."

\footnotetext{
${ }^{1}$ For the purpose of this essay, I shall use the terms "Siam" and "Siamese" in appreciation of the facts that 1] the name "Thailand" was not officially declared until the 20th century, 2) the majority ethnic group known as "Thai" was only one of a myriad of ethnic groups which lived (and continue to live) in that country, and 3] although an exonym, "Siam" was the accepted term used by 17th century Europeans, including Guy Tachard. That said, I have generally replaced toponyms with their modern equivalent in order to aid clarity. Thus "Siam" is "Ayutthaya," "Louvo" is "Lopburi," "Peking" is "Beijing," and so on"; Guy Tachard, A Relation of the Voyage to Siam. Performed by Six Jesuits, Sent by the French King, to the Indies and China, in the Year, 1685: With Their Astrological Observtions, and Thier Remarks of Natural Philosophy, Geography, Hydrography, and History (St. Pauls Church-Yard: Golden-Lyon, 1688], 4-7.

2 Tachard, 4-7.

${ }^{3}$ Tachard, 11-12.

${ }^{4}$ Tachard, 4; King Narai of Siam had sent an earlier embassy in 1681 which was lost off the coast of Mauritius before arriving in France. See: Ian Hodges, "Western Science in Siam: A Tale of Two Kings," Osiris 13 (1998): 80; David R. M. Irving, "Lully in Siam: Music and Diplomacy in French-Siamese Cultural Exchanges, 1680-1690," Early Music 40, no. 3 (2012): 396.

5 Tachard, Voyage de Siam, 5.
} 
by famed Italian Astronomer Giovanni Cassini. ${ }^{6}$ Meanwhile, Louis XIV recruited a group of Jesuits "who might be capable of labouring in consort with the Academy Royal, in the Improvement of Arts and Sciences, and at the same time employ themselves . . in advancing the Christian religion". ${ }^{7}$ One of these priests, Guy Tachard, would record the events of the following year in his book $A$ Voyage to Siam. ${ }^{8}$

Traditional schools of history would have seen this exchange as relatively unimportant. It had little lasting impact on the French or Siamese. Recent developments in the history of early modern science and diplomacy have encouraged historical approaches that emphasize the microinteractions between global actors in exchanges like this one. This paper will use such an approach to demonstrate how these interactions engendered subtle tensions which determined the outcome of this exchange. In doing so, this paper will show how such a historical analysis can break out of Eurocentric representations of global exchange. Furthermore, it more accurately reflects the agency of non-European actors in the success and development of these early modern interactions.

Global exchanges were complex affairs that intertwined religious evangelism, political agendas, and scientific investigation. ${ }^{9}$ Recent trends in the histories of science and diplomacy have aimed to highlight those complexities in opposition to earlier, Eurocentric narratives. Traditional historians of science Joseph Needham and George Basalla both argued that modern science was a uniquely western invention that was spread across the world through European exploration and imperialism. More recently, postpositive thinkers have suggested that modern science was not a uniquely logical system but one of many context-dependent, local systems of knowledge. This model acknowledges the agency of non-European actors in interacting with and transforming knowledge that they came into contact with. Nevertheless, historian Kapil Raj has argued that both positivists (like Needham and Basalla) and post-positivists have operated under the belief that modern science originated in Europe and was subsequently spread to the 'peripheral,' non-European world. In order to actually break out of this eurocentrism, Raj proposed a model that focuses on the global circulation and transformation of early modern knowledge. ${ }^{10}$ Such an approach emphasizes the ways in which knowledge was created and transformed via cross-cultural intellectual exchanges. This provincializes European science,

\footnotetext{
${ }^{6}$ Hodges, "Western Science in Siam: A Tale of Two Kings," 88; Sheila J. Rabin, "Early modern Jesuit Science. A Historiographical Essay," Journal of Jesuit Studies 1, no. 1 (2014): 92, https://doi.org/10.1163/22141332-00101006. ${ }^{7}$ Tachard, Voyage de Siam, 4.

${ }^{8}$ Published in English translation in 1688 in London. Tachard's descriptions of Siam and the Siamese were often suspect and cannot be entirely trusted by historians. This leaves an ambiguous picture of $17^{\text {th }}$ century Siamese society. Nonetheless, Narai's actions imply certain attitudes towards his encounters with the French. One can compare these attitudes to those of the French to better understand the interactions that took place. This essay will use Tachard's account for that purpose, recognizing its limitations as a source. Further study using Thai-language is needed to better understand the dynamics that took place in early modern exchanges in Siam. Unfortunately, English translations of these sources are not currently available, requiring this paper to rely more heavily on Tachard's account than preferable.

${ }^{9}$ Paula Findlen, Empires of Knowledge: Scientific Networks in the Early modern World (Routledge, 2018), 3, https://www.google.com/books/edition/_/2nd0DwAAQBAJ?hl=en\&gbpv=1.

${ }^{10}$ Kapil Raj, "Beyond Postcolonialism... and Postpositivism: Circulation and the Global History of Science," Isis 104 (2013): 338-44.
} 
reflecting its role as $a$ knowledge system which received knowledge from other areas of the world in similar ways that other cultures were exposed to European science. Such an approach balances its representation of European and non-European actors so that the actual inequalities present at the moment of the exchange are not enhanced by Eurocentric perspectives of the historian. This allows for a more accurate analysis of the exchanges that took place.

Similar developments have taken place in the history of diplomacy. Since Garrett Mattingly's 1955 book Renaissance Diplomacy, early modern foreign relations have focused on the establishment of modern, professional diplomacy after the Peace of Lodi in $1454 .{ }^{11}$ More recent historiography has critiqued that model, noting, for instance, that formalized "ambassadors" did not exist in Europe until the mid-17 $7^{\text {th }}$ century or that the term diplomatique did not appear in the Dictionnaire de l'Académie Française until 1762. "New Diplomatic History" has focused on the complex actions of the individuals who facilitated international relations before modern diplomacy was fully established. ${ }^{13}$ Lucien Bély notably described early modern Europe as a "société des princes" which relied on interpersonal relationships between princes to overcome (or fail to overcome) cultural differences. ${ }^{14}$ International relations were developed on personal, professional, and international levels simultaneously. ${ }^{15}$ Historians Maartje van Gelder and Tijana Krstić have emphasized the need to recognize early modern foreign relations as a normative process of renegotiating often-times tense cultural divides. ${ }^{16}$ Thus foreign relations at this time were heavily influenced by relatively small gestures and attitudes brought to an exchange. This "New Diplomatic History" approach gives greater emphasis to these smaller elements of an exchange. This more granular approach to the attitudes and actions that comprised an international exchange provides a more detailed picture of the dynamics of that interaction. This includes the actions of non-European actors and their consequences. Thus this approach, like post-postpositive approach proposed by Raj above, allows the historian to look closer at the active role of non-European actors.

The developments in both the histories of science and diplomacy show that exchanges were dynamic interactions that operated simultaneously on multiple levels. Both of these approaches make it easier to see the contributions of non-European actors to cross-cultural

\footnotetext{
${ }^{11}$ Tracey A. Sowerby, "Early modern Diplomatic History: Early modern Diplomatic History,” History Compass 14, no. 9 (September 2016): 442, https://doi.org/10.1111/hic3.12329.

12 Jan Hennings and Tracey A. Sowerby, "Introduction: Practices of Diplomacy," in Practices of Diplomacy in the Early modern World, n.d., 5; Christian Windler, "Afterward: From Social Status to Sovereignty-Practices of Foreign Relations from the Renaissance to the Sattelzeit," in Practices of Diplomacy in the Early modern World, ed. Tracey A. Sowerby and Jan Hennings, n.d., 254.

${ }^{13}$ E. Natalie Rothman, "Afterword: Intermediaries, Mediation, and Cross-Confessional Diplomacy in the Early modern Mediterranean," Journal of Early modern History 19, no. 2-3 (April 21, 2015): 348, https://doi.org/10.1163/15700658-12342459.

${ }^{14}$ Windler, "Afterward: From Social Status to Sovereignty-Practices of Foreign Relations from the Renaissance to the Sattelzeit," 255-58; Sowerby, "Early modern Diplomatic History," 443; Rothman, “Afterword," 250. See also Sanjay Subrahmanyam.

${ }^{15}$ Hennings and Sowerby, "Introduction: Practices of Diplomacy," 3.

${ }^{16}$ Maartje van Gelder and Tijana Krstić, "Introduction: Cross-Confessional Diplomacy and Diplomatic Intermediaries in the Early modern Mediterranean," Journal of Early modern History 19, no. 2-3 (April 21, 2015): 99, https://doi.org/10.1163/15700658-12342452.
} 
exchanges with Europe in the early modern period. This paper will combine these two approaches, showing how the respective attitudes of the Siamese and the French towards the 1685 French-Siamese exchange led to very different levels of success for each side. The French's attitude of superiority led them to behave in ways that obstructed their goals of conversion and political influence. Meanwhile, the Siamese attitude of curiosity and pluralism enabled them to benefit from the French's visit while preserving their own culture.

This was not Siam's first interaction with Europe. The then-capital city of Ayutthaya (since 1351) sat at the strategic confluence of the Chao Phraya and several other major rivers. Easy access to the sea attracted merchants from across Eurasia. Contact with Europe had been increasing since the 1569 Burmese invasion required the Siamese to raise funds for reconstruction of their capital city. ${ }^{17}$ King Narai likely had a sense for the cultural divide to expect from his European guests when the French embassy arrived on 22 September 1685.

The French had less experience with the Siamese and therefore may have been less prepared for this exchange. As this paper will show, the French approached their relations with Siam with an attitude of cultural superiority. Their judgements of the Siamese prevented the French from learning from the Siamese, limiting the benefit which the French could reap from this exchange.

\section{Political Exchange}

The French and Siamese attitudes towards political exchange were evident in King Narai's initial reception of Chaumont. According to Tachard, Narai treated Chaumont "with marks of distinction from all others, . . . even from those of the Emperor of China." Whether Narai would agree with Tachard that Emperor Kangxi of China was "all over the East ... reckoned the greatest Monarch of the Universe" is debatable. ${ }^{18}$ Nonetheless, Narai certainly seemed ready to disregard precedent in order to welcome the French ambassador. Similarly, when Chaumont objected to the prostration customary in audiences with the King, Narai "said publicly, that he would not have the ancient Ceremonies observed ... which were used at the Reception of the Ambassadors of the Mogul, Persia, and China\{sic\}." Narai granted Chaumont as many audiences as Chaumont desired, among other allowances which "had never been before granted to any Ambassador." ${ }^{19}$ Chaumont was less accommodating than his host. He considered the Siamese "ways of receiving Ambassadors below the Character which he bore" leading to his aforementioned objections. ${ }^{20}$ During his first audience, Chaumont was surprised "to see the King so high above him, and . . . troubled that he had not been told of it." He was supposed to deliver Louis XIV's letter to Narai via a tall, cup-like tray. Chaumont realized that "to reach up to him [Narai], he must have taken the Cup by the lower part of the Foot, and raised his Arm very high, [and] thought that that Distance suited not with his Dignity." Chaumont improvised by holding

\footnotetext{
${ }^{17}$ Hodges, "Western Science in Siam: A Tale of Two Kings," 80-84.

18 Tachard, Voyage de Siam, 154.

19 Tachard, 158-59, 177.

20 Tachard, 158.
} 
"the Bowl [of the cup], and [stretching] his Arm but half out" to which Narai "rose up smiling, and stooping with his Body over the Throne, met him half way to receive the Letter." 21 The tension in this episode is palpable. King Narai, who by custom received ambassadors "crawling along upon his hands" was forced to stretch down to accommodate the French ambassador's hesitation to stretch his arm more than halfway out. ${ }^{22}$

Narai's accommodation in all these instances showed his commitment to the success of the exchange. Chaumont, in contrast, was preoccupied with establishing an appropriately dignified tone. Ceremony was highly regarded in early modern European politics. Relations between states depended on the location, gifts, and details of an official audience. ${ }^{23}$ When a Russian embassy landed in England in 1662, for example, they were immediately greeted by several Englishmen to negotiate the embassy's ceremonial entrance into London and other preferential treatment. That exchange failed when a Russian official tricked an English diplomat into dismounting his horse first, by a fraction of a second. ${ }^{24}$ While this behavior can seem insignificant, much work has been done to show its importance in establishing and maintaining social and international hierarchies. ${ }^{25}$ This punctilious ceremonial language was the backbone of international relations within Europe and an obstacle to it outside of Europe. ${ }^{26}$ Despite this, Narai capably navigated his audience with Chaumont. He allowed the audience to be negotiated to Chaumont's pleasing and suffered Chaumont's faux pas, recognizing the significance of such small actions. Narai's patience with European practices demonstrated his commitment to establishing political ties with the French.

The French returned this favor when they received Narai's third embassy in 1686. They went to great lengths to match the pomp of the Siamese reception in Versailles' Hall of Mirrors. ${ }^{27}$ These were among the "Testimonies of a sincere Friendship" which Chaumont had promised Narai during his first audience. In addition, Chaumont told Narai that the French desired to "entertain and increase Commerce." 28 This was possibly signaled by the large amounts of timepieces, globes, and other scientific equipment which Louis XIV sent for Narai. ${ }^{29}$ In Europe, gift giving was an established and highly symbolic part of political exchanges. Gifts of goods, such as tin and hemp from Russia or cloth from Genoa, were sometimes used to

\footnotetext{
21 Tachard, 171.

22 Tachard, 156.

${ }^{23}$ Hennings and Sowerby, "Introduction: Practices of Diplomacy," 4, 13.

${ }^{24}$ Jan Hennings, "The Failed Gift: Ceremony and Gift-Giving in Anglo-Russian Relations (1662-1664)," in

Practices of Diplomacy in the Early Modern World, ed. Tracey A. Sowerby and Jan Hennings, n.d., $239-44$.

${ }^{25}$ See Christian Windler and Sanjay Subrahmanyam's works on the role of diplomatic ceremonies to maintain crosscultural relations between France and Tunisia and across the Moghul, Ottoman, and Safavid empires respectively in Hennings, 245-48; See also Barbara Stolberg-Rilinger's work on the actualization of power dynamics "in actu” in diplomatic ceremonies in Windler, "Afterward: From Social Status to Sovereignty-Practices of Foreign Relations from the Renaissance to the Sattelzeit," 256-57.

${ }^{26}$ Hennings, "The Failed Gift: Ceremony and Gift-Giving in Anglo-Russian Relations (1662-1664)," 248; Hennings and Sowerby, "Introduction: Practices of Diplomacy," 8.

${ }^{27}$ Irving, "Lully in Siam: Music and Diplomacy in French-Siamese Cultural Exchanges, 1680-1690," 400.

28 Tachard, Voyage de Siam, 169.

${ }^{29}$ Hodges, "Western Science in Siam: A Tale of Two Kings," 89.
} 
encourage trade in those commodities. ${ }^{30}$ The French gifts of scientific instruments may have suggested their desire to open a trade in European knowledge. If this were the case, it would suggest that the French believed their knowledge to be superior to that of the Siamese. This attitude of superiority characterized the French's scientific and religious exchanges as well, as will be shown below.

In contrast, Narai's gifts of vests and "lighter clothes" were given so that the French might "suffer with less inconvenience the great heats of a Climate to which they were not accustomed." Upon receiving these gifts, Chaumont immediately "caused a great deal of Money to be thrown out at the Windows, to the Servants of the Mandarins who brought" them. If this gesture was intended to display French opulence, it certainly had that effect: "There was no other talk for a long time but of that rich shower of Gold and Silver, which fell in the Court of the Ambassador of France." 31 Narai's gifts demonstrated a concern for the Frenchmen's comfort whereas Chaumont's actions demonstrated a concern for their reputation.

The French seemed to approach the reception with Narai in terms of their self-perception. Chaumont worked to represent France as dignified, intellectually advanced, and opulent. Narai's approach, in contrast, was characterized by patience and compromise. He was unwilling to let Siamese customs impede the success of the exchange. Narai saw across the exchange to accommodate the French. Chaumont looked away from the Siamese and towards the concerns of France.

These conflicting attitudes can only be seen when one considers the importance of ceremony and gift-giving in early modern political relations. Narai actively invested in the exchange by trying to make his guests comfortable. Chaumont, in contrast, allowed his belief in French superiority to become an obstacle to his success. Thus individual actions, even those as brief as Chaumont's hesitation to hold out his arm or as informal as Chaumont throwing money outside of his window, are important clues as to the dynamics in this exchange. Through these actions, one can see the attitudes which Narai and Chaumont brought to this exchange. Thus, it is by examining these small and informal actions that "New Diplomatic History" brings more nuance to the examination of early modern exchanges.

\section{Scientific Exchange}

While in the political realm, King Narai and the French envoi were working at crosspurposes, both parties had similar interests when it came to the exchange of knowledge. During his reign, Narai ordered clocks, telescopes, cannons, models of the earth and stars, watches, other

\footnotetext{
${ }^{30}$ Hennings and Sowerby, "Introduction: Practices of Diplomacy," 16; Hennings, "The Failed Gift: Ceremony and Gift-Giving in Anglo-Russian Relations (1662-1664)," 242; Marika Keblusek and Badeloch Vera Noldus, Double Agents: Cultural and Political Brokerage in Early modern Europe (Leiden, UNITED STATES: BRILL, 2011), 24, http://ebookcentral.proquest.com/lib/middlebury/detail.action?docID=737720.

31 Tachard, Voyage de Siam, 175; Chaumont could have been warding off (real or imagined) insinuations of French dependence on Narai. The Mamuk, Safavid, Ottoman, and Mughal courts were all known to gift coats or robes as symbols of patronage or vassalage. See Hennings and Sowerby, "Introduction: Practices of Diplomacy," 16.
} 
pieces of scientific equipment and "other rarities" from Dutch traders. In contrast, his predecessors usually received jewelry, cloth, or spices. ${ }^{32}$ The French knew about Narai's interest in western items. Tachard lists both "the King's Presents" and "a great many Bales of all sorts of Curiosities which the King of Siam had sent for" among the cargo of the Maligne. ${ }^{33}$ If France was looking for an eager market for European science, they found one in King Narai.

The Thai Chronicles remember Narai as a gifted poet, a member of a prominent literary community, and the creator of the first Thai Language textbook. ${ }^{34}$ As his requests for European scientific instruments show, he was also interested in the sciences. Astrology, in particular, played an important role in Siamese society. Dates, including the date of Chaumont's first audience with Narai, were chosen based on astrological calculations. ${ }^{35}$ Hundreds of years of astronomical data, including calculations of the rotation of the sun, earth, and moon, were stored in the official archives. The Siamese were particularly exact; the length of their calendar year averaged only twenty-four minutes different from today's western standard. This had political ramifications. Calendars were symbols of sovereignty in early modern southeast Asia.

Knowledge of the stars was considered an important, royal virtue. ${ }^{36}$ Although, as Historian Ian Hodges argued, the Siamese astronomical tradition was so old and revered that western science did not pose a practical threat to them, Narai was clearly interested in European astronomy. ${ }^{37}$ It is not surprising, then, that a central event of Tachard's account was Narai's observation of a lunar eclipse with the Jesuit mathematicians. ${ }^{38}$

Scientific research had been a part of Jesuit missions since the inception of their order. Jesuit scientific observations were initially encouraged in response to public interest but gradually took on greater and greater importance within the European scientific community. ${ }^{39}$ European intellectuals had been turning away from medieval scholasticism and towards "openair research." 40 The Jesuit José Acosta's late $16^{\text {th }}$ century publication Natural and Moral History of the Indies set a standard for Jesuit missionary science. ${ }^{41}$ Over half of Tachard's account consisted of details about the flora, fauna, medicine, peoples, histories, religions, cultures, and astronomical events that he encountered. ${ }^{42}$ The priests' astronomical observations were

\footnotetext{
${ }^{32}$ Hodges, "Western Science in Siam: A Tale of Two Kings," 88.

33 Tachard, Voyage de Siam, 12. Emphasis Mine.

${ }^{34}$ Hodges, "Western Science in Siam: A Tale of Two Kings," 87-90.

35 Tachard, Voyage de Siam, 142.

${ }^{36}$ Hodges, "Western Science in Siam: A Tale of Two Kings," 84-86.

${ }^{37}$ Hodges, 90.

38 Tachard, Voyage de Siam, 191.

${ }^{39}$ Findlen, Empires of Knowledge: Scientific Networks in the Early modern World, 59-60.

${ }^{40}$ A. Grafton, N.G. Siraisi, and A. Shelford, New Worlds, Ancient Texts: The Power of Tradition and the Shock of Discovery, ACLS Humanities E-Book (Belknap Press of Harvard University Press, 1992), 3; "Recherche en Plein Air" coined by Michel Callon, see: Kapil Raj, Relocating Modern Science: Circulation and the Construction of Knowledge in South Asia and Europe, 1650-1900 (Houndmills, Basingstoke, Hampshire [England]; New York: Palgrave Macmillan, 2007), 14.

${ }^{41}$ Findlen, Empires of Knowledge, 60.

42 Tachard, Voyage de Siam, 25-35, 63-72, 96-107, 263-308.
} 
particularly important because of their relevance to European cartography. ${ }^{43}$ Tachard and his colleagues were members of the French Académie Royal des Sciences, which was known for excellent cartography and was one of the many European institutions which collaborated with the Jesuit order. ${ }^{44}$ As such, they were constantly correcting charts, making astronomical observations, and building observatories. ${ }^{45}$ Scientific investigation was a primary concern for the French Jesuits on this mission.

The priests' scientific mission was enacted in concert with their religious agenda. Early on, the Society of Jesus discovered that knowledge of European science helped missionaries gain the confidence of locals. ${ }^{46}$ Matteo Ricci, a $16^{\text {th }}$ century Jesuit missionary to China, made inroads in intellectual circles by teaching Euclidean geometry, Mercator cartography, and Tychonian astronomy. ${ }^{47} \mathrm{He}$ dressed like Chinese literati and closely studied Confucianism and the Chinese language. ${ }^{48} \mathrm{He}$ insisted that more mathematicians should be sent to China to aid his mission. ${ }^{49}$ Tachard and his colleagues likely hoped to recreate Ricci's success in Siam, especially given Narai's special inclination towards western science. ${ }^{50}$ The priests must have seen Narai's desire to share the lunar eclipse observation as a positive step towards his conversion. A commitment to western science was a key element in the Jesuit's religious agenda.

Narai provided a house outside the city for the observations to take place. "A more convenient place could not have been chosen" according to Tachard. They "saw the heavens on all hands, and had room enough to place [their] Instruments." The night of the eclipse, the priests "prepared a very good Telescope for [the King] . . in the Window" When the moment was ripe, "notice was sent to the King, who immediately came to that Window .. . We saluted his Majesty with a profound inclination of Body, and then began to observe." Narai quizzed the priests with questions like "Why did the Moon appear reversed in the Telescope? . . What a Clock was it at Paris? . . For what could Observations made by concert in remote Countries be useful?" A local, "Bramen [sic] Astrologer" had asked the priests similar questions, such as "how many fixed stars [the priests] reckoned" there were. ${ }^{51}$ These are similar to the questions which European scientists had been grappling with for the previous century. ${ }^{52}$ Narai and the Astrologer

\footnotetext{
${ }^{43}$ Findlen, Empires of Knowledge: Scientific Networks in the Early modern World, 63-66, 82-88; Raj, Relocating Modern Science, 14-15.

${ }^{44}$ Findlen, Empires of Knowledge: Scientific Networks in the Early modern World, 85; Raj, Relocating Modern Science, 14-15.

${ }^{45}$ See Tachard, Voyage de Siam, 24-25, 49-53, 59, and 117 for a criticism of Father Perdies' map of the southern stars, the establishment of an observatory at the Cape of Good Hope, a criticism of the maps of the Cape of Good Hope, and an attempt to make observations near Batavia, respectively.

${ }^{46}$ Findlen, Empires of Knowledge: Scientific Networks in the Early modern World, 61.

47 Findlen, 64.

${ }^{48}$ Rabin, "Early modern Jesuit Science. A Historiographical Essay," 102.

${ }^{49}$ Findlen, Empires of Knowledge: Scientific Networks in the Early modern World, 64.

${ }^{50}$ In fact, Tachard was meant to continue with his colleagues on to China had his plans not changed during his stay in Siam. Tachard, Voyage de Siam, 5.

51 Tachard, 232-42.

${ }^{52}$ Cf. Kepler's Mysterium Cosmigraphicum published in 1597, for instance. A principal argument in that work tried to preserve the medieval concept of planetary "spheres" via a theory of nestled platonic solids. See J. V. Field,
} 
saw the potential to increase their knowledge by tapping into that of the European priests. Although it is hard to tell what exactly Narai had hoped to accomplish during this observation, Tachard noted that Narai "expressed a particular Satisfaction" with it. ${ }^{53}$ Narai arranged for an observatory to be built, with French help, to rival those in Paris and Beijing. ${ }^{54} \mathrm{He}$ asked Tachard, who was returning to France to arrange for the observatory, to help his ambassadors bring back twelve French mathematicians as well. Narai promised that "before their Arrival, there would be an Observatory, a House and a Church for them" in Siam's two principal cities. ${ }^{55}$ From Narai's perspective, the observation was a successful exchange of scientific practices, one he was eager to encourage.

That perspective was not necessarily shared. Curiosity in the lunar eclipse united Narai and the priests. Yet, they were divided by their two very different agendas. The French priests were concerned with the data that they were collecting for Europe and not with Narai's curiosity. After the King retired, Tachard remarked that his "many Favors to which it behoved us to answer ... hindered us from observing the immersion of several Spots." ${ }^{" 56}$ It is not difficult to imagine that the priests suffered Narai's questioning as one suffers the questions of a child, with patience and frustration. Tachard's published data tables, totaling two and a half pages long, show that the priests were making observations every few minutes. ${ }^{57}$ Publishing this empirical data raw suggests that Tachard believed it would be used by scientists in Europe. The priests were absorbed in their task. Narai's questions were likely seen as interruptions of important, European work. Narai and the priests' different agendas separated them even while they shared the eclipse observation.

In any case, Tachard had only a marginal interest in Siamese knowledge traditions. Tachard noted that the aforementioned Brahmin astrologer, "had foretold this Eclipse to a quarter of an hour almost; but he was mightily mistaken as to the duration of it." 58 This recognition of the Astrologer's skills was qualified with terms like "almost" and "mightily mistaken." Tachard's patronization implies that the French considered their skills superior. This, despite the fact that the priests admittedly failed to understand the Astrologer's calculations due to the language barrier. This is the only point in Tachard's account where a language barrier prevented communication. The fact that this communication broke down could be because of the technical nature of the topic or it could be that there was not enough effort to engage a suitable translator. It seems that the priests did not take the Brahmin seriously as a scholar. Later, he assured his readers that "I will say nothing but what I have seen myself, or what I have learned from . . . some other very intelligent Persons, that I may not impose upon the public by false or uncertain reports . . . as to the Orientals, all know that they tell things not really as they are, but as they

\footnotetext{
Kepler's Geometrical Cosmology (London: The Athlone Press, 1988), 112; Note Tachard's dismissal of these questions as "easily answered." Tachard, Voyage de Siam, 242.

${ }_{53}^{53}$ Tachard, Voyage de Siam, 238.

${ }^{54}$ Tachard, 202-3.

55 Tachard, 238-39.

56 Tachard, 240.

${ }^{57}$ Tachard, 237-42.

${ }^{58}$ Tachard, 242.
} 
fancy you could wish they were." 59 This shows that Tachard placed a high value on his direct observations and a low value on reports from locals. His preoccupation with his own investigations led him to dismiss Siamese knowledge.

In contrast to traditional histories of science, more recent approaches have emphasized the "often violent imposition of 'rationality' on cultures originally endowed with 'another reason'."60 Tachard's dismissal of Siamese knowledge, although not literally violent, demonstrated how early European scientists focused on empirical data collection and not the exchange of knowledge. Within the traditional model of European 'rationality' spread to the nonEuropean world, this exchange could be described as European astronomy being imposed on the Siamese. Yet, one can see that King Narai and the Siamese were active agents in the success of their knowledge exchange, not passive recipients of European science. Raj's model, in which knowledge was created and transformed at moments of exchange, better represents the dynamics that were at play in this exchange. The Siamese body of knowledge was expanded via Narai's actions to accumulate European science. In a sense, this acculturated European science into a wider body of Siamese knowledge. The exchange was an adoption (or at least, introduction) of European knowledge to Siam, not an imposition. On the French side, there was no exchange of knowledge. The Jesuits were collecting data while actively distrusting the knowledge provided to them by the local Siamese. This contrast is epitomized in the image of King Narai, using a European telescope, being ignored by the Jesuit priests sitting a few feet away. The French gained knowledge in the form of their empirical data, but those data were not the result of crosscultural interaction. This exchange was not an instance of European 'rationality' being brought to or imposed on the non-European Siamese. Rather, this exchange demonstrated how knowledge creation was dependent upon Narai's active investment in cross-cultural exchange.

\section{Religious Exchange}

King Narai's investment in this exchange, and the French's' sense of superiority, was most blatant when it came to religious differences. There is little ambiguity in how Tachard and his peers viewed the Siamese religion. Tachard repeatedly referred to the "blindness" of the local Buddhists which "made us [the French] pity them." ${ }^{\text {" } 11}$ When the French were not talking about the Siamese "blindness," they commented on how "addicted" they were to their religion. ${ }^{62}$ When Ambassador Chaumont mentioned his desire to convert King Narai to one of Narai's ministers, the minister "seemed astonished at it, and told the Ambassador . . that there was no appearance of effecting it; that the King was extremely addicted to the Religion of his Ancestors." 63

Chaumont, in return, said that he would consider this "but that he could hardly supress the most

\footnotetext{
${ }^{59}$ Tachard, 263-64.

${ }^{60}$ Raj, Relocating Modern Science, 6.

${ }^{61}$ Tachard, Voyage de Siam, 145, 187.

62 Tachard, 192.

63 Tachard, 159.
} 
considerable, and almost Sole Reason for his Voyage." ${ }^{64}$ Even though Chaumont was not a Jesuit himself, his admission that conversion was the primary purpose of this embassy shows how important the question of religion was for the French. The (secular) French desire to convert Narai may have been motivated by a desire, conscious or unconscious, to bring Narai's Siam under the intellectual-religious influence of King Louis XIV. The French held a proto-imperialist belief that they were justified in directing the religion of the Siamese. Chaumont counselled Narai that "To submit Your Grandeur to this [Christian] God who governs Heaven and Earth, is much more Rational, Sir, than . . to the other Deities that are worshiped in the East."65 As in the intellectual exchanges, the French looked down on the local, Siamese traditions while promoting their own views. ${ }^{66}$

The French were not devoid of interested in the Siamese religion. In one instance, Chaumont "had been told so much of [the Temple of the Palace], and of the Idols that are in it, that he had a great mind to see them." Tachard's lengthy descriptions of what Chaumont saw suggests a genuine interest in the contents of these temples. The "most precious ... Idol of the Kingdom," Tachard described, "reaches up to the Roof. . . but what is most surprising, it is all of Gold. Of the Bigness it ... must needs contain above an hundred picks of that Metal, and be worth at least twelve Millions six hundred thousand Livers." 67 This description of what, according to Tachard, was the most sacred statue in the kingdom, starts at a place of curiosity, goes through a state of amazement (at the size and magnificence of the statue), and ends at a judgement of the monetary worth of the statue. The French failed to grasp the religious significance of these statues. Instead, they understood them via European standards of the value, e.g. of gold by weight. In doing so, they assumed Siamese culture could conform to European standards of value.

Tachard also attempted to understand the Siamese religion but he relied on ideas of Christianization to do so. In particular, he admired the morality of the Siamese Buddhists. "As to manners and the way of living," he noted, "a Christian cannot enjoyn \{sic\} anything more perfect than what their [the Siamese] religion prescribes to them. It . . not only prohibits them bad actions, but also every sinful desire, thought, and intention." He further commented that King Narai was "already half a Christian, in the favourable dispositions of his mind and heart."68 Tachard equated morality with Christianity. Seeing Siamese morality, Tachard assumed this implied an affinity with Christianity. The Siamese resistance to fully embrace Christianity must have frustrated Tachard. He found some explanation for this resistance in his understanding of Thevathat, the brother of the Buddhist god Sommonokhodom. Thevathat was punished, according to Tachard's description, by being nailed to a cross, given a crown of thorns, and

\footnotetext{
64 Tachard, 8.

65 Tachard, 170.

66 The Siamese practiced a local form of Buddhism, although Tachard never used that term. My understanding of Thai Buddhism is too limited to correct Tachard's inaccuracies. I have used the term "Siamese religion" to reflect this limitation.

${ }^{67}$ A pick is a unit of weight Tachard, Voyage de Siam, 180-81.

68 Tachard, 302-8.
} 
being sent to Hell. Tachard concluded that, "nothing makes them [the Siamese] more averse from [the Christian Law] than ... the similitude that is to be found betwixt their Religion and ours, making them believe that Jesus Christ, is the very same with that Thevathat." ${ }^{69}$ Tachard saw this coincidental misunderstanding as the obstacle preventing Siamese conversion. This misunderstanding had to be overcome to help the Siamese continue down the path towards conversion. Tachard's understanding of the Siamese religion was based in a perception of their progress towards Christianization. Like Chaumont, Tachard's approach to the Siamese religion revealed his desire to bring Siam into conformity with Europe.

Compare this to King Narai's statements on religion. When one of his ministers delivered a final appeal sent by Chaumont, Narai expressed surprise that the French believed he would convert. "It is strange to me," Narai said, according to Tachard, "that the King of France, my good Friend, should so much concern himself in an Affair that relates to God, wherein it would seem God does not at all interest himself, but leaves it wholly to our Discretion." Narai held that "Unity in Religion [depends] absolutely on Divine Providence, who could as easily introduce it into the World, as [he could] the diversity of Sects." Narai concluded, "ought not one to think that the true God takes as great pleasure to be honoured by different Worships and Ceremonies"? ${ }^{70}$ These beliefs were reflected in Narai's government. A growing Muslim community, largely composed of Safavid traders, had been fostered in Siam since the $16^{\text {th }}$ century. ${ }^{71}$ King Song Tham (1610-1628) established the position of Chularajmontri, or minister of Muslim affairs, to support this community. ${ }^{72}$ Tachard and his companions witnessed large Muslim celebrations during their stay. ${ }^{73}$ Muslims seem to have coexisted comfortably with the Siamese Buddhists. Similarly, Narai was said to have protected Christian missionaries, built churches, and given charity to priests in China ${ }^{74} \mathrm{He}$ was said to have had a "singular veneration" for the two images of the Virgin Mary and Jesus Christ given to him by the Pope. Out of respect, he "hath placed them in a very high place of his Chamber ... and never speaks of them but with honour and respect." 75 Narai even had "two lovely Crucifixes" of gold and silver made for Tachard and a royal priest in France. ${ }^{76}$ Narai revered these objects because they were sacred to the European Christians, not out of his own estimation of their worth. Narai fostered a community which valued a religion through the eyes of its followers. He saw no need to force his views on the Christian or Muslim communities in Siam.

This religious exchange reflected how the attitudes of Narai and the French dictated the outcome of their encounter. The French's self-perceived superiority, as established in the previous sections of this essay, demanded a complete conversion of King Narai. Narai's

\footnotetext{
${ }^{69}$ Tachard, 296-97.

${ }^{70}$ Tachard, 223-24.

${ }^{71}$ M. Ismail Marcinkowski, "Iranians, Shayk Al-Islams and Chularajmontris: Genesis and Development of an Institution and Its Introduction to Siam," Journal of Asian History 37, no. 2 (2003): 193.

${ }^{72}$ Marcinkowski, 195.

${ }^{73}$ Tachard, Voyage de Siam, 214-15.

${ }^{74}$ Tachard, 222.

75 Tachard, 229.

${ }^{76}$ Tachard, 239.
} 
veneration of Christian imagery and treatment of Christian visitors still fell short of the French's desire for him to renounce other religions and become a Christian. In contrast, Narai's curiosity drove him to accept the French, to treat his Christian visitors well, and to venerate the images of Christ and the Virgin Mary that were given to him. In this way, Narai learned about the French and Christians without sacrificing the beliefs that he already held. The French left the exchange religiously empty-handed. They did not have the loyalty of a newly Christian monarch that they had set out to find. Thus one can see that the attitudes revealed in the political and scientific exchanges likewise determined the outcome of this religious exchange for each party.

\section{Conclusion}

This embassy never had a considerable impact on either party. The French received the Siamese in 1686 and the Siamese received the French once more in $1687 .{ }^{77}$ The French failed to convert Narai before he was killed in a coup in $1688 .^{78}$ The new King Phetracha promptly ended relations with Europe. ${ }^{79}$ According to historian Ian Hodges, the interest and impact of Western knowledge in Siam died with King Narai. ${ }^{80}$

French memories of Siam would linger into the $18^{\text {th }}$ century social critiques of Voltaire and Dufresny. ${ }^{81}$ Perhaps Voltaire referenced Siam in his Treatise on Tolerance because he recognized the French attitudes of cultural superiority highlighted by this embassy to Siam. Although the influence of this exchange was politically and intellectually short lived, the attitudes which were present at that exchange lived on, in some sense, in Voltaire's treatise.

A traditional approach to this exchange would have represented it as an instance of European intellectual aggression against a non-European country. The French were engaging in a form of proto-imperialist aggression. Although they were motivated by a desire to advance their knowledge of the world through religious and political relationships, they did so without the ability or willingness to imagine themselves in community with foreigners. They understood Siam in terms of its conformity, or lack thereof, with Europe. At the end of his account, Tachard considered Narai "now ... wholly French." The "great consequences of such a conquest," he continued, "are visible enough, if we consider that the King of Siam hath no less Authority over the Princes his Neighbours . . than he hath over his own Subjects." 82 Tachard believed that the French had subsumed Narai, his kingdom, and his vassal states, into a sphere of French influence. This passage demonstrated very clearly the aggression in the French's attitude. They approached this encounter with Siam as one of conquest, desiring to draw Siam into a world

\footnotetext{
${ }^{77}$ Irving, "Lully in Siam: Music and Diplomacy in French-Siamese Cultural Exchanges, 1680-1690,” 393.

${ }^{78}$ Irving, 407; Michael Smithies, "Young Beuregard (c.1665-c.1692): Soldier of Misfortune in Siam," Journal of the Royal Asiatic Society 8, no. 2 (July 1998): 232.

${ }^{79}$ Hodges, "Western Science in Siam: A Tale of Two Kings," 90.

${ }^{80}$ Hodges, 80.

${ }^{81}$ Irving, "Lully in Siam: Music and Diplomacy in French-Siamese Cultural Exchanges, 1680-1690," 412.

${ }^{82}$ Tachard, 308.
} 
centered around France and Europe. In this way, the French attitude in this exchange could be described as a form of proto-imperialism.

While such an interpretation would not be an inaccurate representation of the French, it would miss an important half of the narrative. Narai sent his embassies to France specifically in order to engage in a cultural exchange. His most overt desire was to attract European scientists and scientific equipment. This can be seen, symbolically and literally, as a desire to see the world through the eyes (and telescopes) of the Europeans. Yet, this was meant to enhance, not to replace, Siamese knowledge traditions. Additionally, Narai's promise to build churches and houses shows his eagerness to invite Christian Europeans into Siamese society. Narai was intentionally bringing Europe into Siam to expand the Siamese understanding of the world. This exchange was not primary driven by French proto-imperialism but rather by Siamese curiosity.

Counter-intuitively, this proto-imperialist attitude demonstrates how early modern global exchanges cannot be simplified into Manichean models of European aggression against nonEuropean peoples. Success in this exchange was founded in the actors' attitudes, not in European power. Looking at this event through the attitudes of each actor prevents non-European actors from being reduced to European foils. Through the use of "New Diplomatic History" and Kapil Raj's post-post-positive history of science, one can better understand the ways in which parties' attitudes towards an exchange played an influential role in the exchange's dynamics. Thus, this approach enables one to more accurately see that the 1685 French-Siamese was driven by King Narai's active accommodation and curiosity. Applying a similar approach to other moments in early modern cross-cultural exchanges will surely revolutionize the way we understand the agency of non-European peoples in their encounters with Europe. 


\section{Bibliography}

Field, J. V. Kepler's Geometrical Cosmology. London: The Athlone Press, 1988.

Findlen, Paula. Empires of Knowledge: Scientific Networks in the Early Modern World. Routledge, 2018.

Gelder, Maartje van, and Tijana Krstić. "Introduction: Cross-Confessional Diplomacy and Diplomatic Intermediaries in the Early Modern Mediterranean." Journal of Early Modern History 19, no. 2-3 (April 21, 2015): 93-105. https://doi.org/10.1163/1570065812342452.

Grafton, A., N.G. Siraisi, and A. Shelford. New Worlds, Ancient Texts: The Power of Tradition and the Shock of Discovery. ACLS Humanities E-Book. Belknap Press of Harvard University Press, 1992.

Hennings, Jan. "The Failed Gift: Ceromony and Gift-Giving in Anglo-Russian Relations (16621664)." In Practices of Diplomacy in the Early Modern World, edited by Tracey A. Sowerby and Jan Hennings, n.d.

Hennings, Jan, and Tracey A. Sowerby. "Introduction: Practices of Diplomacy." In Practices of Diplomacy in the Early Modern World, n.d.

Hodges, Ian. "Western Science in Siam: A Tale of Two Kings.” Osiris 13 (1998): 80-95.

Irving, David R. M. "Lully in Siam: Music and Diplomacy in French-Siamese Cultural Exchanges, 1680-1690." Early Music 40, no. 3 (2012): 939-420.

Keblusek, Marika, and Badeloch Vera Noldus. Double Agents: Cultural and Political Brokerage in Early Modern Europe. Leiden, UNITED STATES: BRILL, 2011.

Marcinkowski, M. Ismail. "Iranians, Shayk Al-Islams and Chularajmontris: Genesis and Development of an Institution and Its Introduction to Siam." Journal of Asian History 37, no. 2 (2003): 187-204.

Rabin, Sheila J. "Early Modern Jesuit Science. A Historiographical Essay." Journal of Jesuit Studies 1, no. 1 (2014): 88-104.

Raj, Kapil. "Beyond Postcolonialism... and Postpositivism: Circulation and the Global History of Science.” Isis 104 (2013): 337-47.

Raj, Kapil. Relocating Modern Science: Circulation and the Construction of Knowledge in South Asia and Europe, 1650-1900. Houndmills, Basingstoke, Hampshire [England]; New York: Palgrave Macmillan, 2007. 
Rothman, E. Natalie. "Afterword: Intermediaries, Mediation, and Cross-Confessional Diplomacy in the Early Modern Mediterranean.” Journal of Early Modern History 19, no. 2-3 (April 21, 2015): 245-59.

Smithies, Michael. "Young Beuregard (c.1665-c.1692): Soldier of Misfortune in Siam." Journal of the Royal Asiatic Society 8, no. 2 (July 1998): 229-35.

Sowerby, Tracey A. "Early Modern Diplomatic History." History Compass 14, no. 9 (September 2016): 441-56. https://doi.org/10.1111/hic3.12329.

Tachard, Guy. A Relation of the Voyage to Siam. Performed by Six Jesuits, Sent by the French King, to the Indies and China, in the Year, 1685: With Their Astrological Observtions, and Thier Remarks of Natural Philosophy, Geography, Hydrography, and History. St. Pauls Church-Yard: Golden-Lyon, 1688.

Windler, Christian. "Afterward: From Social Status to Sovereignty_Practices of Foreign Relations from the Renaissance to the Sattelzeit." In Practices of Diplomacy in the Early Modern World, edited by Tracey A. Sowerby and Jan Hennings, n.d. 